\title{
Relationships among basin area, sediment transport mechanisms and wood storage in mountain basins of the Dolomites (Italian Alps)
}

\author{
E. Rigon, F. Comiti, L. Mao \& M. A. Lenzi \\ Department of Land and Agro-Forest Environments, \\ University of Padova, Legnaro, Padova, Italy
}

\begin{abstract}
The present work analyses the linkages between basin geology, shallow landslides, streambed morphology and debris flow occurrence in several small watersheds of the Dolomites (Italian Alps). Field survey and GIS analysis were carried out in order to seek correlations among basin area, basin geology, spatial frequency of landslides, in-channel wood storage, and local bed slope.

Keywords: large woody debris, landslides, bed morphology, Alps.
\end{abstract}

\section{Introduction}

Along with sediments, shallow landslides in forested basins supply channels with wood elements, which may have a strong impact on both channel morphology/stability and on debris flow dynamics.

Headwater channels, which make up $60-80 \%$ of the cumulative channel length in mountainous terrain $[10,11]$, are characterized by a strong coupling between hillslope and channel processes, in contrast to lowland streams. The switch between different transport mechanisms (e.g., bedload transport to debris flows) in the same channel often depends on the occurrence of shallow landslides feeding sediment in otherwise sediment-limited systems. Along with sediments, shallow landslides in forested basins supply channels with wood elements, which may have a strong impact on both channel morphology/stability 
and on debris flow dynamics. Large wood in the U.S Pacific Northwest and in Japan is long recognised to greatly influence the dynamics of debris flow channels, whereas poorly is known about its role in the European Alps.

Debris flows can transport large amount of wood $[1,6]$, which interact with the sediment-water mixture [4] and favour deposition. In steep headwater channels relative wood storage is higher than in lowland streams [2, 9] mostly because wood elements are very large compared to channel dimensions and thus are hardly transportable downstream by ordinary flows. Wood (along with sediment) tends to accumulate within these channels and only debris flow events can transport it substantially downstream and deposit it on alluvial fans and at confluences with higher-order tributaries $[3,7,12]$.

The present work aims to evaluate wood load in mountain basins of varying size $\left(1.2\right.$ to $70 \mathrm{~km}^{2}$ ) of the Dolomites (Eastern Italian Alps) and to determine how wood input and transport processes change with basin scale.

\section{Study sites and survey methods}

\subsection{Basin descriptions}

The location of the 13 study basins is shown in Figure 2. The channels drain calcareous, sedimentary and igneous mountain catchments in the Southeastern Alps, within the administrative boundaries of the Province of Belluno, Italy.Table 1 reports a summary of the most important characteristics of the study basins. The location of the thirteen basins that are the subject of the present research is shown in fig. 1. Precipitation (1100 mm annual average) falls mainly in spring and autumn as cyclonic, long-duration rainfall, and as snowfall from December through April. Short-duration, intense summer rainstorms cause flash floods in the smaller basins (generally $<2-3 \mathrm{~km}^{2}$ ), where debris flow phenomena are very frequent. Sediment sources in the form of talus slopes, shallow landslides, bank erosion and slow mass movements are widespread but their abundance differs considerably according to the geology of each basin.

Forest cover (Table 1) of the basins - the upper tree limit is around 2000$2100 \mathrm{~m}$ a.s.1. - is mostly represented by conifers: spruce (Picea abies) within the elevation range 1000-1600 $\mathrm{m}$ a.s.1., whereas the upper zone (1600-2000 $\mathrm{m}$ a.s.1.) features mixed spruce-larch (Larix decidua) stands. No old-growth stands exist in the basins. In Italy as a whole, clear-cutting was banned at the beginning of last century to prevent soil erosion and increase soil retention capacity for flood attenuation. Only small areas $\left(<100 \mathrm{~m}^{2}\right)$ are now logged contiguously. Nonetheless, the ruggedness of the terrain is such that most of the forested area is not harvested because it is unprofitable. Therefore, effects of logging slash on inchannel woody debris are expected to be small or negligible. Riparian vegetation is constituted by broadleaves at the lowest elevations $(<1400-1500 \mathrm{~m}$ a.s.1.) mostly alder (Alnus incana) with minor presence of ash (Fraxinus excelsior), maple (Acer pseudoplatanus), and willow (Salix spp) - and by spruce and larch in the upper part of the channels. Conifer trees typically have diameters on average around $0.3-0.4 \mathrm{~m}$, whereas riparian broadleaves feature smaller sizes $(<0.3 \mathrm{~m})$. 


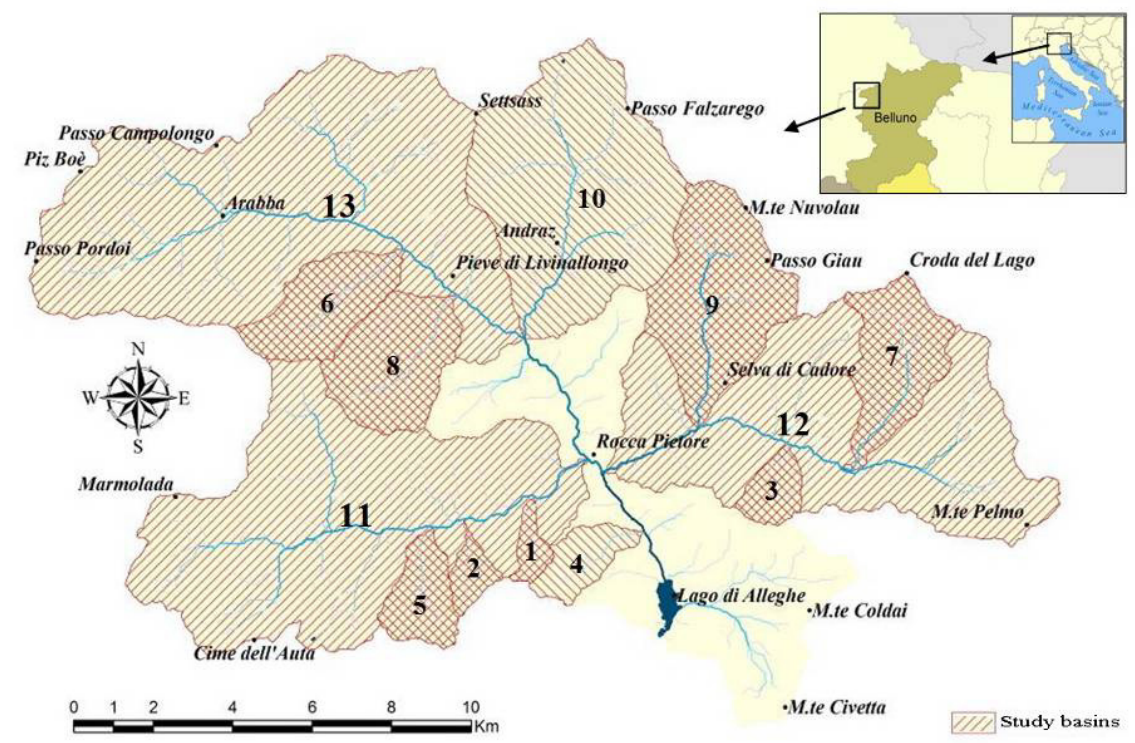

Figure 1: Location map of the study basins (northeastern Italy). Numbers refer to Table 1.

Table 1: $\quad$ General characteristic of the study basins.

\begin{tabular}{|c|c|c|c|c|c|c|c|c|}
\hline Basin & $\begin{array}{c}\text { Stream } \\
\text { order }\end{array}$ & $\begin{array}{l}\text { Area } \\
\left(\mathrm{Km}^{2}\right)\end{array}$ & $\begin{array}{c}\text { Forested } \\
\text { area } \\
\%\end{array}$ & $\begin{array}{c}\text { Mean } \\
\text { elevation } \\
(m \text { a.s.l.) }\end{array}$ & $\begin{array}{c}\text { Mean } \\
\text { basin } \\
\text { slope } \\
(\%)\end{array}$ & $\begin{array}{c}\text { Channel } \\
\text { length } \\
(K m)\end{array}$ & $\begin{array}{c}\text { Mean } \\
\text { channel } \\
\text { slope } \\
(\%)\end{array}$ & $\begin{array}{c}\text { Dominant bed } \\
\text { morphology }\end{array}$ \\
\hline 1- Bianco ${ }^{a}$ & 1 & 1,2 & 69 & 1724 & 72 & 2,2 & 38 & cascade / bedrock \\
\hline 2- Miniere ${ }^{a}$ & 1 & 1,5 & 57 & 1886 & 75 & 1,9 & 28 & falls / bedrock \\
\hline 3- Code $^{a}$ & 2 & 2,2 & 89 & 1776 & 41 & 1,7 & 26 & cascade/ bedrock \\
\hline 4- Molini & 2 & 2,9 & 91 & 1609 & 51 & 3,6 & 16 & step-pool / bedrock \\
\hline 5- Valbona & 2 & 3,8 & 49 & 1888 & 76 & 3 & 21 & cascade \\
\hline 6- Ornella & 2 & 6,7 & 53 & 1961 & 54 & 4,6 & 18 & cascade \\
\hline 7- Cordon & 3 & 7,7 & 32 & 2075 & 47 & 5,5 & 10 & step-pool \\
\hline 8- Davedino & 2 & 8,7 & 48 & 1961 & 60 & 4 & 16 & cascade \\
\hline 9- Codalunga & 4 & 13,5 & 43 & 1930 & 55 & 6,4 & 10 & cascade / step-pool \\
\hline 10- Andraz & 4 & 27,2 & 44 & 1950 & 49 & 7,7 & 13 & cascade / step-pool \\
\hline 11- Pettorina & 4 & 51 & 41 & 1944 & 65 & 12,9 & 6 & artificial / riffles $^{c}$ \\
\hline 12- Fiorentina & $5^{b}$ & $58^{b}$ & 51 & 1838 & 55 & 12 & 4 & artificial / riffles ${ }^{c}$ \\
\hline 13- Cordevole & 5 & 70 & 29 & 1194 & 51 & 13,3 & 3 & artificial / riffles ${ }^{c}$ \\
\hline
\end{tabular}

${ }^{\text {a }}$ Field evidences of debris flows.

${ }^{\mathrm{b}}$ Actual drainage area at the downstream end section surveyed is $37 \mathrm{~km}^{2}$ and stream order is 4 .

${ }^{\mathrm{b}}$ Sequences of concrete check-dams. 
166 Monitoring, Simulation, Prevention and Remediation of Dense Debris Flows II
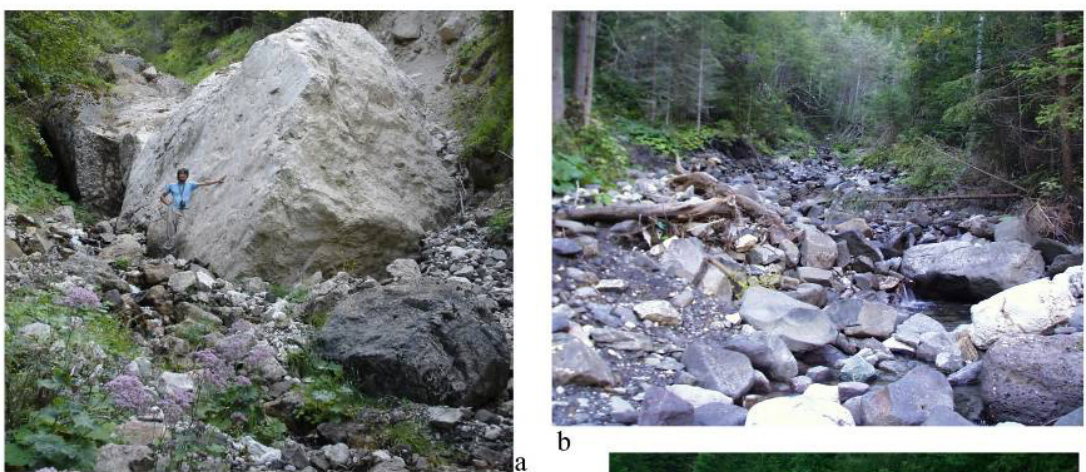

\section{b}
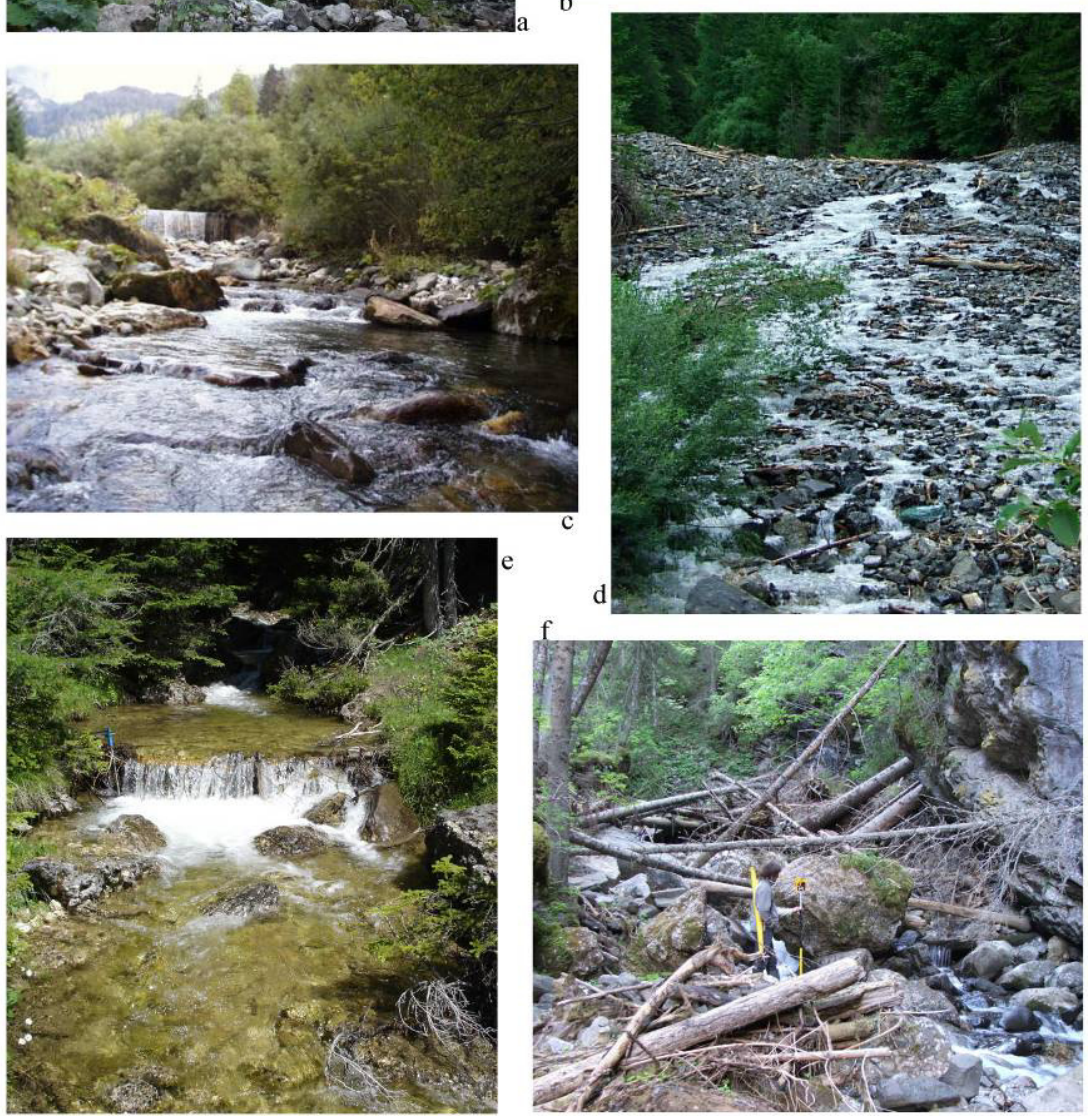

Figure 2: Photos of the study channels: (a) Rio Bianco; (b) depositional reach in the Rio Code; (c) View of the Fiorentina; (d) debris flow fan deposited within the Cordevole (e) log step in the Rio Andraz; (f) wood-rich segment of the Rio Davedino. 


\subsection{Survey methodology}

Field surveys were carried out from April 2004 to September 2007. Most streams were surveyed along the entire length of the main channel, whereas a systematic sampling scheme was adopted in some basins (Rio delle Miniere, Valbona, Ornella, Andraz and Rio Bianco), with 500-700 m-long segments were a-priori selected and which summed to $10 \%$ of the total channel length. Channel reaches were identified in the field based on uniformity of either slope, channel width, or abundance of wood. Bankfull width, depth and mean slope were measured in each reach. Bank erosions, landslides and tributary debris flow channels (fig. 2) were also recorded. All wood pieces $>5 \mathrm{~cm}$ in diameter and $>0.5 \mathrm{~m}$ in length lying within the active channel were measured by a tree calibre and tape meter respectively. Wood elements and wood jams were also classified as to their qualitative aspects $[2,8]$. The volume of each log was calculated assuming a cylindrical shape, and wood storage for each reach was then derived as the total wood volume divided by channel area (i.e., bankfull width times reach length).

Basin area drained at each reach was calculated from a $5 \mathrm{~m} \times 5 \mathrm{~m}$ Digital Elevation Model using GIS software.

\section{Results}

\subsection{Channel width and slope as a function of drainage area}

As expected, a positive correlation (based on log-transformed values, $\mathrm{R}=0.72$, $\mathrm{p}<0.05)$ is observed between bankfull width (W) and drainage area (A) at the reach scale (Fig. 3). However, for $A>20 \mathrm{~km}^{2}$, a large scatter is present due to the

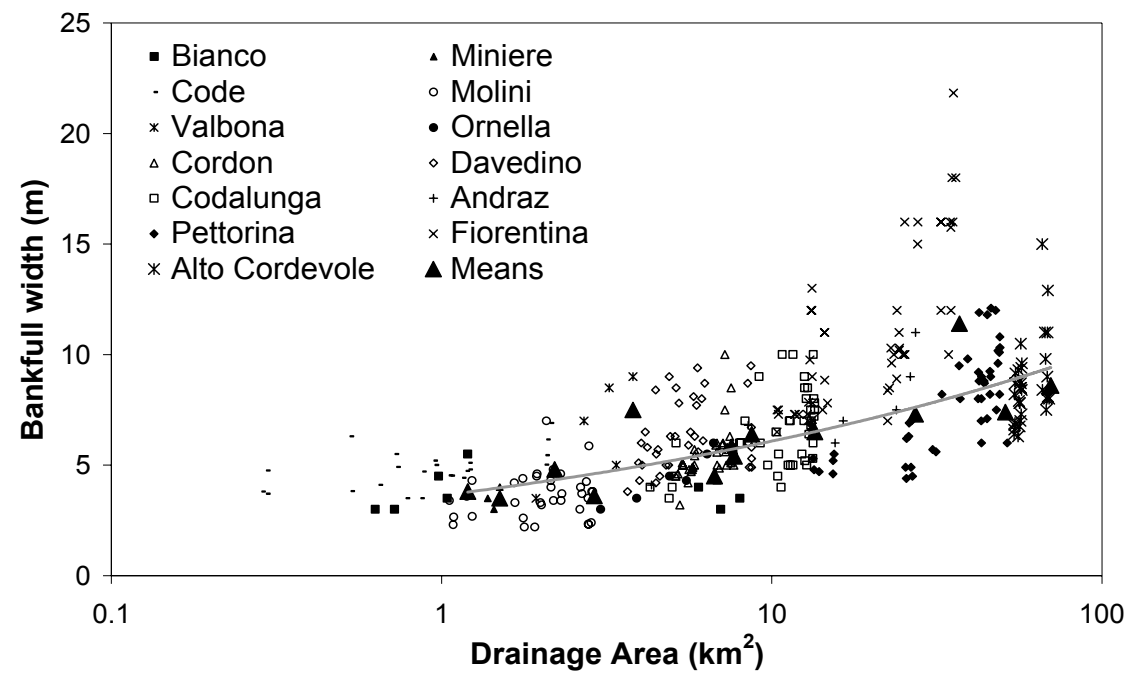

Figure 3: $\quad$ Scatter plot of the bankfull width in relation to drainage area. 
presence - in the Pettorina, Cordevole and Fiorentina rivers - of reaches whose cross-section was artificially widened when longitudinal and grade-control works were constructed. On the other hand, for $\mathrm{A}<1.5 \mathrm{~km}^{2}$, channel widths are fairly constant, around $5 \mathrm{~m}$. This is likely due to the frequent occurrence of debris flows in the smaller basins analysed here [5].

The best-fit curve interpolating the average channel width for each basin (basin-scale analysis) is the following:

$$
W=3.82 \cdot A^{0.21}
$$

with $\mathrm{R}^{2}=0.64$ (but $\mathrm{p}>0.05$ ).

As to mean channel slope (S), it turned out to be inversely correlated to drainage area (Fig. 4). The correlation - based on log-transformed data - is $\mathrm{R}=-$ $0.82(\mathrm{p}<0.05)$.

The regression curve calculated on basin-averaged slope values reads as:

$$
S=39.42 \cdot A^{-0.38}
$$

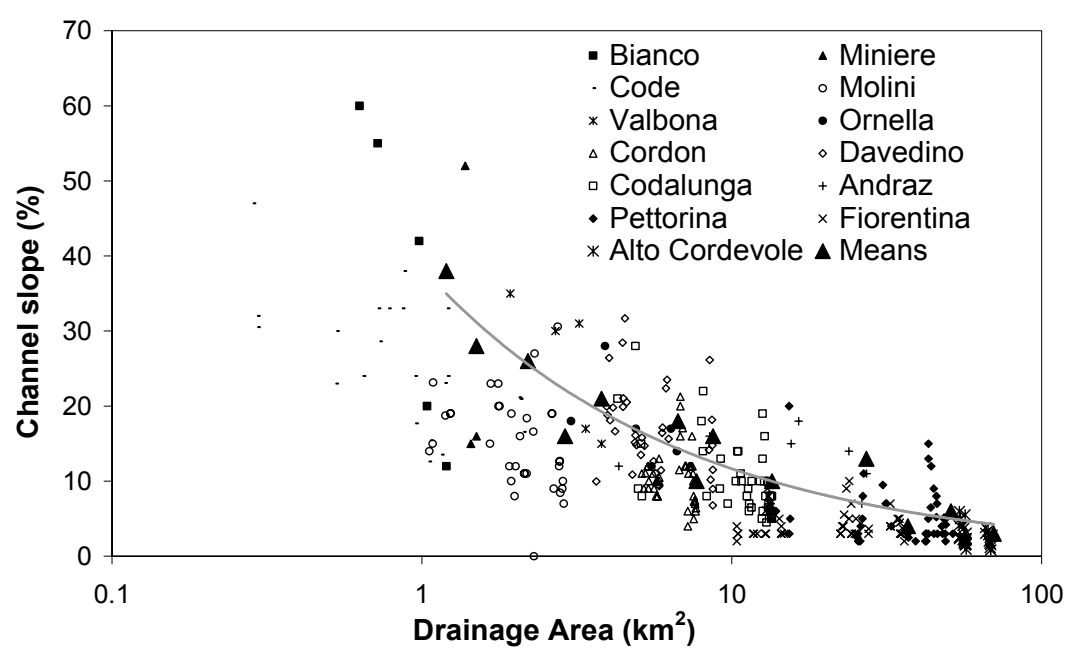

Figure 4: $\quad$ Scatter plot of the channel slope in relation to drainage area.

\subsection{Wood dimensions and storage in the study basins}

More than 9,000 wood elements were counted in the field survey (Table 2). Median log diameters $\left(\mathrm{D}_{50}\right)$ do not vary considerably among the study basins $(0.08-0.13 \mathrm{~m})$, whereas large differences exist with regard to log length $\left(\mathrm{L}_{50}=\right.$ $0.79-3,75 \mathrm{~m})$, but no correlation was found with basin size. In contrast, the ratio between the $84^{\text {th }}$ percentile of log length and the average channel width $\left(\mathrm{L}_{84} \mathrm{Bkf}^{-1}\right)$ remains close to 1 for channels $<3^{\text {rd }}$ order $\left(\mathrm{A}<10 \mathrm{~km}^{2}\right)$, and drops for higher-order basins (down to 0.2-0.3), with a correlation with basin area of $\mathrm{R}=0.68(\mathrm{p}<0.1)$. The ratio between the $84^{\text {th }}$ percentile of $\log$ diameters and the average channel depth $\left(\mathrm{D}_{84} \mathrm{Dph}^{-1}\right)$ it's always less than 0.5 . 
Table 2: $\quad$ In-channel stored wood: quantity and sizes.

\begin{tabular}{lcccccccccc}
\hline Basin & $\mathbf{N}^{\circ}$ pieces & $\begin{array}{c}\text { Vol wood } \\
\left(m^{3}\right)\end{array}$ & $\begin{array}{c}\mathbf{D}_{16} \\
(m)\end{array}$ & $\begin{array}{c}\mathbf{D}_{50} \\
(m)\end{array}$ & $\begin{array}{c}\mathbf{D}_{84} \\
(m)\end{array}$ & $\begin{array}{c}\mathbf{L}_{16} \\
(m)\end{array}$ & $\begin{array}{c}\mathbf{L}_{50} \\
(m)\end{array}$ & $\begin{array}{c}\mathbf{L}_{84} \\
(m)\end{array}$ & $\mathbf{D}_{84} \mathbf{D p h}^{-1}$ & $\mathbf{L}_{84} \mathbf{B k f}^{-1}$ \\
\hline Cordevole & 775 & 52.4 & 0.06 & 0.09 & 0.17 & 0.8 & 1.7 & 3.8 & 0.27 & 0.44 \\
Andraz & 159 & 37.5 & 0.08 & 0.13 & 0.25 & 1.3 & 3.5 & 10.0 & 0.49 & 1.37 \\
Bianco & 77 & 9.3 & 0.06 & 0.11 & 0.23 & 0.7 & 1.2 & 3.7 & 0.49 & 0.96 \\
Codalonga & 818 & 42.9 & 0.05 & 0.07 & 0.14 & 1.0 & 2.9 & 6.4 & 0.26 & 0.98 \\
Code & 767 & 54.1 & 0.05 & 0.10 & 0.22 & 0.9 & 1.8 & 5.1 & 0.48 & 1.06 \\
Cordon & 602 & 44 & 0.05 & 0.11 & 0.18 & 1.2 & 2.1 & 5.8 & 0.25 & 1.07 \\
Davedino & 2013 & 191.1 & 0.07 & 0.12 & 0.22 & 0.9 & 2.0 & 5.0 & 0.32 & 0.78 \\
Miniere & 184 & 6.86 & 0.06 & 0.10 & 0.20 & 0.6 & 1.2 & 3.2 & 0.46 & 0.91 \\
Fiorentina & 1557 & 97.53 & 0.05 & 0.10 & 0.19 & 1.0 & 1.7 & 3.9 & 0.33 & 0.34 \\
Molini & 655 & 40.04 & 0.06 & 0.10 & 0.20 & 0.8 & 1.6 & 4.0 & 0.42 & 1.11 \\
Ornella & 119 & 4.42 & 0.05 & 0.07 & 0.12 & 1.0 & 1.7 & 3.9 & 0.26 & 0.87 \\
Pettorina & 1320 & 50.76 & 0.05 & 0.08 & 0.14 & 0.4 & 0.8 & 1.6 & 0.25 & 0.22 \\
Valbona & 44 & 4.4 & 0.05 & 0.11 & 0.18 & 0.9 & 2.8 & 5.1 & 0.46 & 0.68 \\
\hline
\end{tabular}

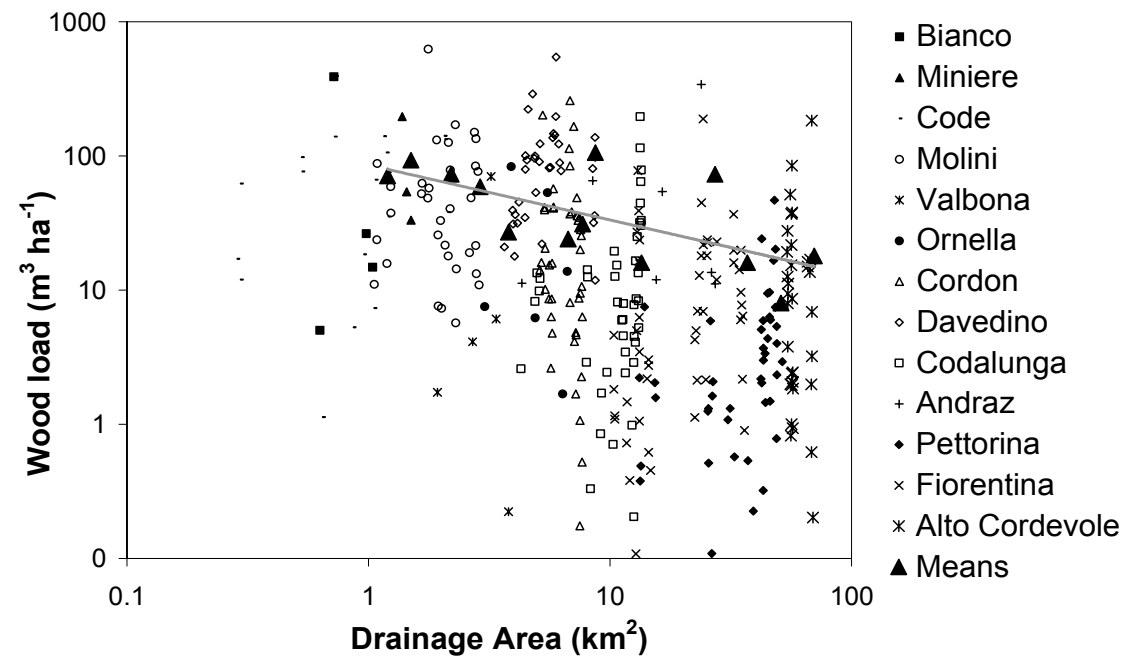

Figure 5: Scatter plot of the in-channel volume of stored wood (in relation with the surface channel) and the drainage area.

Therefore, a much higher mobility of wood elements might be envisaged for such channels [9], and this could be a reason for their lower wood load per unit of bed area $\left(\mathrm{V}_{\mathrm{w}}\right.$, Fig. 5). However, these larger basins present also higher degrees of human impact (roads, towns, control works) which are presumed to contribute to diminish the presence of in-channel wood. On the other hand, extremely high wood loads $\left(>70 \mathrm{~m}^{3} \mathrm{ha}^{-1}\right)$ can be found in relatively large catchments too, as the 
case of the Andraz creek $\left(A=27.2 \mathrm{~km}^{2}\right)$. However, because this stream was surveyed using the partial sampling procedure (see above), this indication must be regarded with caution. The best-fit regression curve on basin-averaged wood loads is as follows:

$$
V_{w}=84.92 \cdot A^{-0.31}
$$

The relationship features a very low $R^{2}(0.33)$ and is significant only at $\mathrm{p}<0.10$. Two basins (Andraz and Davedino) appear to lower the correlation with drainage area, plotting well above the power trend curve. Indeed, Fig. 5 shows a very large scatter of the reach-based wood loads $(R=-0.39, p<0.05)$.

\subsection{Hillslope instabilities and wood storage}

The scatter is Fig. 5 indicates that several factors other than basin/channel size affect wood load. During the field surveys became evident that reaches storing high wood volumes were associated to the presence of landslides or debris flow tributaries (fig. 2b,2d,2f) which supply streams with large conifer trees.
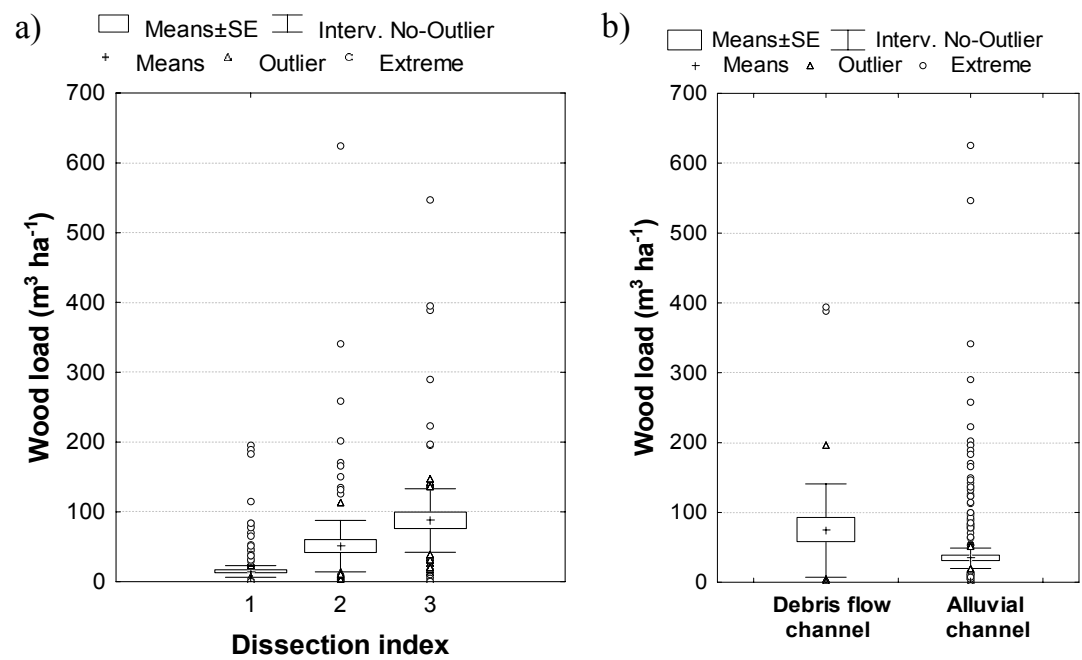

Figure 6: Box and whisker plot of the variation in the in-channel volume of stored wood in relation to a) dissection index: $1=$ low $2=$ medium $3=$ higth b) Debris flow-prone channels.

During the survey, each reach was given a score reflecting - along its banks the linear extension of landslides, bank erosions, and/or the confluence with debris flow channels. In order to calculate a "dissection index" (DI) at the basin scale, reach-scale values were averaged weighted on reach length, and each basin was then assigned to one of three classes (1-3) with increasing degrees of dissection. Figure 6a shows that wood load on average increases with DI. Looking instead at differences in wood load between debris flow and alluvial 
channels (Fig. 6b), these are less clear to due to high number of outliers present in the latter. A two-way ANOVA including as factors the dissection index and the channel type (debris flow vs. alluvial) was carried out. Results confirms the statistical relevance of DI (Fig. $7 \mathrm{a}, \mathrm{p}<0.01$ ) whereas the difference between channel types (Fig. 7b) is not significant ( $p>0.10)$. However, debris flow channels (Miniere, Bianco, Code) seem to present smaller wood loading. It is important to mention that basin-averaged DI is correlated negatively with drainage area $(\mathrm{R}=-0,66, \mathrm{p}<0.05)$ and positively with channel slope $(\mathrm{R}=0.57$, $\mathrm{p}<0.05)$.

a)

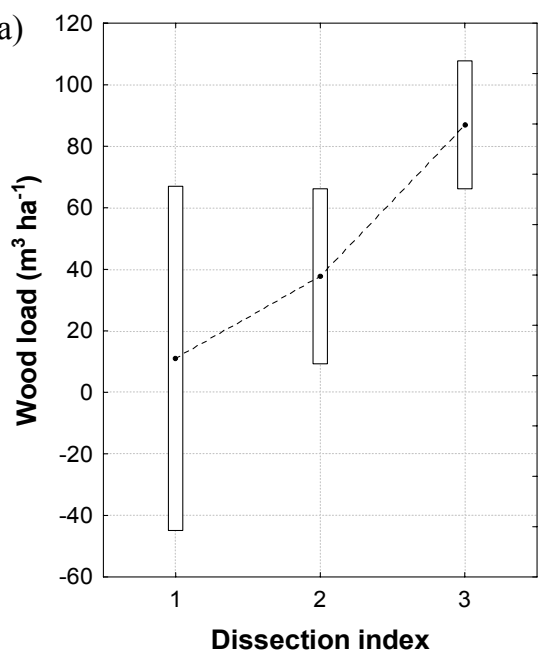

b)

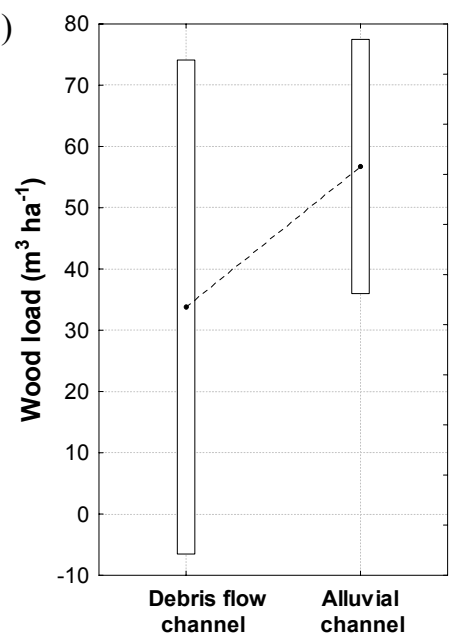

Figure 7: Variance analysis. The vertical box indicating confidence intervals to $95 \%$ a) dissection index b) Debris flow-prone channels.

\section{Conclusions}

High wood loading in mountain channels of the Dolomites tend to be more frequent in low order $\left(<3^{\text {rd }}, \mathrm{A}<10 \mathrm{~km}^{2}\right)$ channels, but appears to be strongly associated to the degree of basin instability encompassing landslides and debris flows tributaries. However, wood mobility in these narrow streams is very limited and is likely to become substantial only with infrequently large flood events, or when debris flows occur in the channels. Wood transfer is potentially more efficient for higher order streams, thus leading to a higher frequency of wood-related hazards (e.g., bridge obstructions). Therefore, to reduce flood hazards associated to excessive wood transport, priority should be given to: i) prevent large mass wasting in forested areas; ii) design bridges taking into account wood transport; and, only if economically worth, iii) build trapping structures in debris flow channels entering directly large (order $>4$ ) streams and/or in these large channels upstream of sensitive locations (towns, bridges). 


\section{References}

[1] Bigelow, P.E., Benda, L.E., Miller, D.J. and Burnett, K.M. On Debris Flows, River Networks, and the Spatial Structure of Channel Morphology Forest Science 53(2) 220-238, 2007.

[2] Comiti F., Andreoli A., Lenzi M.A., and Mao L. Spatial density and characteristics of woody debris in five mountain rivers of the Dolomites (Italian Alps). Geomorphology 78, Issues 1-2, 44-63, 2006.

[3] Dietrich W.E., Dunne, T. Sediment budget for a small catchment in mountainous terrain. Zeitschrift fur Geomorphologie N.F. 29:191-206, 1978.

[4] Lancaster, S.T., Hayes, S.K. and Grant, G.E. Effects of wood on debris flow runout in small mountain watersheds. Water Resour. Res. 39(6): 1168doi: 10.1029/2001WR001227, 2003.

[5] Leopold, L.B., and Maddock, T. Jr., The hydraulic geometry of stream channels and some physiographic implications, U.S. Geol. Surv. Prof. Pap., $252,1953$.

[6] May, C.L. Debris flows through different forest age classes in the central Oregon Coast Range, J. Am. Wat. Resourc. Assoc., 38(4), 1097-1113, 2002.

[7] May, C.L., Gresswell, R.E. Process and rates of sediment and wood accumulation in headwater streams of the Oregon Coast Range, USA. Earth Surface Processes and Landforms 28, 409-424, 2003

[8] Rigon E., Andreoli A., Comiti F., Lenzi M.A. Quantity, characteristic and origin of large woody debris in a mountain stream (Codalunga, Veneto). Quaderni di Idronomia Montana 25, 227-243, 2007

[9] Rigon E., Comiti F., Andreoli A., Lenzi M.A. Wood in mountain streams of the Alps: too much or too little? Evidences from the upper Cordevole basin (Belluno) Quaderni di Idronomia Montana accepted.

[10] Schumm, S.A. Evolution of drainage systems and slopes in badlands at Perth Amboy, New Jersey. Bulletin of the Geological Society of America 67: 597-646, 1956.

[11] Shreve, R.L. Stream lengths and basin areas in topologically random channel networks. Journal of Geology 77: 397-414, 1969.

[12] Swanson F.J., Fredricksen, R.L., McCorison, F.M. Material transfer in a western Oregon forested watershed. In Analysis of Coniferous Forest Ecosystems in the Western United States, Edmonds RL (ed.). Hutchinson Ross: New York; 233-266, 1982. 